\title{
Maslinic Acid Inhibits Proliferation of Renal Cell Carcinoma Cell Lines and Suppresses Angiogenesis of Endothelial Cells
}

\author{
Parth Thakor, ${ }^{1,3}$ Wenzhe Song, ${ }^{2}$ Ramalingam B. Subramanian, ${ }^{3}$ Vasudev R. Thakkar, ${ }^{3}$ \\ David A. Vesey, ${ }^{1,4}$ Glenda C. Gobe ${ }^{1}$
}

${ }^{1}$ Centre for Kidney Disease Research, School of Medicine, Translational Research Institute, The University of Queensland, Brisbane, Queensland, Australia; ${ }^{2}$ Department of General Surgery, Affiliated Hospital to Xuzhou Medical University, Xuzhou, China; ${ }^{3}$ B. R. D. School of Biosciences, Sardar Patel University, Vallabhvidyanagar, Gujarat, India; ${ }^{4}$ Department of Renal Medicine, The University of Queensland at Princess Alexandra Hospital, Brisbane, Queensland, Australia

\begin{abstract}
Despite the introduction of many novel therapeutics in clinical practice, metastatic renal cell carcinoma (RCC) remains a treatment-resistant cancer. As red and processed meat are considered risk factors for RCC, and a vegetable-rich diet is thought to reduce this risk, research into plant-based therapeutics may provide valuable complementary or alternative therapeutics for the management of RCC. Herein, we present the antiproliferative and antiangiogenic effects of maslinic acid, which occurs naturally in edible plants, particularly in olive fruits, and also in a variety of medicinal plants. Human RCC cell lines (ACHN, Caki-1, and SN12K1), endothelial cells (human umbilical vein endothelial cell line [HUVEC]), and primary cultures of kidney proximal tubular epithelial cells (PTEC) were treated with maslinic acid. Maslinic acid was relatively less toxic to PTEC when compared with RCC under similar experimental conditions. In RCC cell lines, maslinic acid induced a significant reduction in proliferation, proliferating cell nuclear antigen, and colony formation. In HUVEC, maslinic acid induced a significant reduction in capillary tube formation in vitro and vascular endothelial growth factor. This study provides a rationale for incorporating a maslinic acid-rich diet either to reduce the risk of developing kidney cancer or as an adjunct to existing antiangiogenic therapy to improve efficacy.
\end{abstract}

Keywords: angiogenesis; maslinic acid; proliferating cell nuclear antigen; renal cell carcinoma; vascular endothelial growth factor

Received: 12 February 2017; Accepted after revision: 27 February 2017; Published: 21 March 2017.

Author for correspondence: Glenda C. Gobe, MSc, PhD, Centre for Kidney Disease Research, Translational Research Institute, University of Queensland School of Medicine, 37 Kent Street, Woolloongabba, Queensland 4102, Australia. Email: g.gobe@uq.edu.au

How to cite: Thakor P, Song W, Subramanian RB, Thakkar VR, Vesey DA, Gobe GC. Maslinic Acid Inhibits Proliferation of Renal Cell Carcinoma Cell Lines and Suppresses Angiogenesis of Endothelial Cells. J Kidney Cancer VHL 2017;4(1):16-24.

Doi: http:/ /dx.doi.org/10.15586/jkcvhl.2017.64

Copyright: The Authors.

License: This open access article is licensed under Creative Commons Attribution 4.0 International (CC BY 4.0). http://creativecommons.org/licenses/by/4.0

\section{Introduction}

Renal cell carcinoma (RCC) is a highly metastatic, heterogeneous disease that is resistant to conventional treatment modalities. In the past decade, the introduction of many novel targeted therapeutics, mostly tyrosine kinase inhibitors (TKIs) targeting the angiogenesis pathway, has marginally increased progression-free and overall survival rates $(1,2)$. Resistance to therapy continues to be a major challenge in the effective treatment of metastatic RCC patients $(3,4)$. About $30 \%$ of patients are inherently resistant to TKIs, and the remaining $70 \%$ who initially respond to treatment eventually develop resistance (5-7). There is an immense need to 
find novel anticancer agents to combat this deadly disease. The contribution of plant-derived natural products to cancer therapy has been widely acknowledged (8). The best examples are the taxanes paclitaxel and docetaxel, derived from the genus Taxus (9).

Research into plant-based potential alternative or complementary therapies is particularly important given that red and processed meat are thought to be risk factors for the development of RCC (10-12) and that a vegetable-rich diet is considered to reduce the risk $(13,14)$. Maslinic acid is a pentacyclic triterpenoid that occurs naturally in edible plants, particularly in olive fruits, and also in a variety of medicinal plants $(15,16)$. Maslinic acid has been shown to have antioxidant (17), anti-inflammatory (18), antimalarial (19), antiprotozoan (20), antidiabetic (21), and anti-HIV-1 activities (22). In addition, in vitro, maslinic acid has been shown to exert proapoptotic effects on many human cancer cell lines including colon (15), prostate (23), bladder (24), and lung (25). The predominant mechanism appears to be induction of apoptosis through the inhibition of various antiapoptotic molecules including nuclear factor- $\kappa \mathrm{B}$ and the antiapoptotic Bcl-2 family members $(15,26)$. To our knowledge, the effect of maslinic acid on $\mathrm{RCC}$ has not been reported. In the current study, we explored the anticancer and antiangiogenic effects of maslinic acid in RCC cell lines and endothelial cells, respectively. Maslinic acid exerted significant anticancer and antiangiogenic properties. The major mechanism appears to be inhibition of proliferation rather than induction of apoptosis.

\section{Materials and Methods}

\section{Ethics approval}

Approvals for the collection and use of primary cultures of human proximal tubular epithelial cells were obtained from the Human Research Ethics Committee of the Princess Alexandra Hospital and the Human Ethics Committee of University of Queensland, Brisbane, Australia. Written informed consent was obtained from patients before the collection of samples.

\section{Cells and compounds}

Maslinic acid ( $>98 \%$ purity) was purchased from SigmaAldrich (St. Louis, MO; Cat No. M6699-5MG). Maslinic acid was dissolved in dimethyl sulfoxide (DMSO) and further diluted in cell culture medium to the desired concentration. The compound was freshly prepared immediately before use. The human RCC cell lines ACHN and Caki-1, and the human umbilical vein endothelial cell (HUVEC) line were obtained from ATCC. Another human metastatic RCC cell line, SN12K1, was obtained from Professor D. Nicol, formerly at Princess Alexandra Hospital, Brisbane, Australia, through his collaborations with Dr I. J. Fidler, Cancer Research Institute, MD Anderson Cancer Center, Orlando, FL. Primary cultures of morphologically normal human kidney proximal tubular epithelial cells (PTECs) were isolated and maintained as per our previous publication (27). The RCC cell lines were maintained as a monolayer in DMEM/F12 (Gibco; Invitrogen, Carlsbad, CA) containing 10\% fetal bovine serum (Gibco; Invitrogen, Carlsbad, CA) supplemented with $50-\mathrm{U} / \mathrm{ml}$ penicillin and $50-\mu \mathrm{g} / \mathrm{ml}$ streptomycin, at $37^{\circ} \mathrm{C}$ in a humidified atmosphere of $5 \% \mathrm{CO}_{2} / 95 \%$ air.

\section{MTT Assay for Cell Viability}

Cell viability in response to maslinic acid treatment was analyzed as per our previous report (28). In brief, $3 \times 10^{3}$ cells per well per $100 \mu \mathrm{l}$ were seeded in 96 -well culture plates and incubated for 24 hours. The cells were treated with various concentrations of maslinic acid, and after 24 hours of incubation, $5 \mu \mathrm{l}$ of MTT, from a stock of $5 \mathrm{mg} / \mathrm{ml}$ in phosphate buffered saline (PBS), was added to each well and incubated for 90 minutes at $37^{\circ} \mathrm{C}$ in a humidified atmosphere of $5 \%$ $\mathrm{CO}_{2} / 95 \%$ air. After the incubation period, the culture medium was removed and the purple crystals formed were dissolved in $100 \mu \mathrm{l}$ of DMSO. The absorbance was recorded using a microplate reader at $570 \mathrm{~nm}$ with a reference wavelength of $690 \mathrm{~nm}$. The $\mathrm{IC}_{50}$ values were calculated from the absorbance.

\section{Assessment of Apoptosis and Proliferation}

Morphological assessment of apoptosis and proliferation was performed as per previous publication (28). In brief, $5 \times 10^{4}$ cells were seeded on a cover slip in 24 -well culture plates. After 24 hours, cells were treated with their respective $\mathrm{IC}_{50}$ values of maslinic acid. After an incubation period of 24 hours, the culture medium was removed, and cells were fixed with $4 \%$ formalin. Hematoxylin and eosin staining was performed to study the morphology of proliferating cells and apoptotic cells. The cells were viewed under a $40 \times$ microscope objective, and the cells that fell within the 100 squares of an eye graticule were counted. Apoptotic nuclei were determined based on their distinct morphological features: hyperchromasia, shrunken/condensed nuclei, blebbing of the membrane while maintaining membrane integrity, crescent nuclei, and apoptotic bodies (29). Proliferating cells were identified by the conspicuous visibility of chromosomes, various stages of mitosis with a visible metaphase plate, and cytokinesis. Apoptotic and proliferating cells were expressed as a percentage of the total cells counted from five random fields for each cover slip.

\section{Colony formation assay}

Colony formation assay of RCC cell lines was performed as per our previous publication (30). Briefly, $1 \times 10^{3}$ RCC cells were seeded in six-well plates. Three hours later, the culture medium was removed and the plates were washed with culture medium to remove unattached cells. The cells were incubated in culture medium with or without maslinic acid and cultured 
for 10 days. The medium was removed at the end of experiments, the cells were washed in PBS, fixed in 4\% formalin, washed in PBS, and stained with $0.5 \%$ crystal violet aqueous stain. The cells were washed until no stain came out, air dried, and photographed. The dye was extracted using DMSO and then quantified using a spectrophotometer at $590 \mathrm{~nm}$.

\section{In vitro angiogenesis}

An in vitro angiogenesis assay was performed as described previously (31). Briefly, 96-well plates were coated with $50 \mu \mathrm{l}$ of Matrigel (BD Biosciences, North Ryde, NSW, Australia) and allowed to solidify for 60 minutes at $37^{\circ} \mathrm{C}$. HUVEC were dispersed in culture medium with or without maslinic acid ( $24 \mu \mathrm{M}$, which is half the $\mathrm{IC}_{50}$ value for HUVEC). The cells were then seeded on the Matrigel at a density of $3 \times 10^{4}$ cells $/ 100 \mu$ l. After 6 hours, the cells were photographed under a phase-contrast microscope. The number of tubes and the average length of tube per field were determined.

\section{Gene expression studies}

Cells were grown to approximately $90 \%$ confluence in $6-\mathrm{cm}$ petri dishes and treated with or without maslinic acid. Twentyfour hours later, total RNA was isolated using PureLink RNA Mini Kit (Life Technologies, VIC, Australia) as per the manufacturer's protocol and quantified with Nano drop (Thermo Fisher Scientific, VIC, Australia). cDNA was synthesized using a High Capacity cDNA Reverse Transcription Kit (Life Technologies). In brief, $1 \mu \mathrm{g}$ of RNA in a RT-PCR reaction mixture ( $2 \mu \mathrm{l} 10 \times$ buffer, $0.8 \mu \mathrm{l}$ dNTP, $2 \mu \mathrm{l}$ r-hex, $1 \mu$ l enzyme, water to $20 \mu \mathrm{l}$ per reaction) was subjected to the following PCR conditions: $25^{\circ} \mathrm{C}$ for 10 minutes, $37^{\circ} \mathrm{C}$ for 120 minutes, $85^{\circ} \mathrm{C}$ for 5 minutes followed by holding at $4^{\circ} \mathrm{C}$. The cDNA was diluted to $50 \mu \mathrm{l}$ with $30 \mu \mathrm{l}$ of RNAse-free water. Fully validated TaqMan Gene Expression Assay (Life Technologies) for vascular endothelial growth factor A (VEGFA; Hs00900055 $\mathrm{m} 1$ ), interleukin-6 (IL-6; Hs00985639_m1), interleukin-8 (IL-8; Hs00174103_m1), proliferating cell nuclear antigen (PCNA; Hs00427214_g1), Bcl2-associated X protein (BAX; Hs00180269_m1), B-cell lymphoma 2 (Bcl2; Hs00236808_ s1), and tight junction protein 1 (TJP-1; Hs01551861_m1) was used with SensiFAST TM Probe No-ROX Kit (Bioline, London, UK) in a LightCycler 480 (Roche Applied Science, Penzberg, Germany) to determine relative gene expression by the comparative $\mathrm{Ct}$ method. The TATA box binding protein (TBP Hs00427620_m1; Life Technologies) was used as internal control, and for normalization.

\section{Statistical analyses}

The data were analyzed using Student's $t$-test, and $P<0.05$ was considered significant. The experiments were performed in duplicates with $\mathrm{n}=6$ for each set. The results are expressed as mean \pm standard error.

\section{Results}

\section{Maslinic acid is toxic to RCC cell lines}

The $\mathrm{IC}_{50}$ values of the RCC cell lines and PTEC, after 24 hours of treatment with maslinic acid, are shown in Table 1. Of the three RCC cell lines, SN12K1 was the most susceptible with an $\mathrm{IC}_{50}$ value of $47.11 \mu \mathrm{M}$ and $\mathrm{ACHN}$ was the most resistant with an $\mathrm{IC}_{50}$ value of $76.52 \mu \mathrm{M}$. As toxicity is one of the major limiting factors in conventional chemotherapy, it was essential to test the toxicity of maslinic acid in noncancerous, morphologically normal proximal tubular cells. As expected, PTEC from nine donors showed varying responses. Although all PTEC showed a higher $\mathrm{IC}_{50}$ value than SN12K1, demonstrating selective toxicity of maslinic acid to this cell RCC cell type, five of nine PTEC (PTEC 4, 6, 7, 8, and 9) showed a higher $\mathrm{IC}_{50}$ value than $\mathrm{ACHN}$ and Caki-1. Thus, maslinic acid is relatively less toxic to PTEC when compared with RCC under similar experimental conditions. For further experiments, the respective $\mathrm{IC}_{50}$ values of each RCC cell lines were used.

\section{Maslinic acid did not induce apoptosis in RCC cell lines}

To find the mechanism of maslinic acid-induced cytotoxicity, the proapoptotic effect of maslinic acid on the RCC cells was studied. After 24 hours of treatment, maslinic acid did not induce any significant changes in apoptosis (Figure 1A). To further confirm these findings at a molecular level, expression of the antiapoptotic gene $\mathrm{Bcl} 2$ and the proapoptotic gene Bax was studied by validated human TaqMan

Table 1. $\mathrm{IC}_{50}$ values of cells

\begin{tabular}{|l|c|}
\hline Cell Line & $\mathrm{IC}_{50}(\mu \mathrm{M})$ \\
\hline ACHN & $76.52 \pm 3.45$ \\
\hline Caki-1 & $67.14 \pm 1.02$ \\
\hline SN12K1 & $47.11 \pm 2.86$ \\
\hline PTEC 1 & $60.16 \pm 4.82$ \\
\hline PTEC 2 & $65.83 \pm 5.70$ \\
\hline PTEC 3 & $66.50 \pm 5.02$ \\
\hline PTEC 4 & $97.04 \pm 6.28$ \\
\hline PTEC 5 & $63.17 \pm 2.77$ \\
\hline PTEC 6 & $88.90 \pm 5.19$ \\
\hline PTEC 7 & $92.50 \pm 2.84$ \\
\hline PTEC 8 & $85.50 \pm 3.60$ \\
\hline PTEC 9 & $89.80 \pm 2.90$ \\
\hline
\end{tabular}



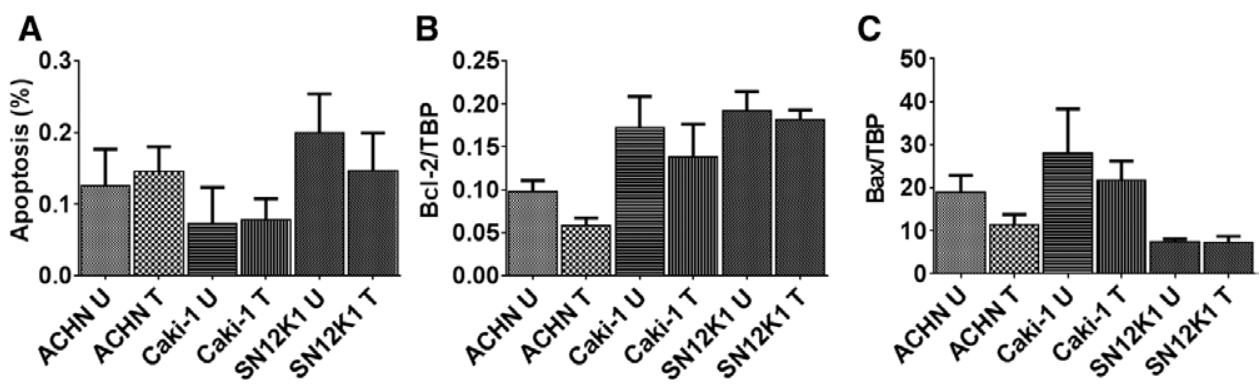

Figure 1. Lack of effect of maslinic acid on apoptosis and apoptosis-regulatory molecules. The effect of maslinic acid on apoptosis of RCC was studied 24 hours after incubating the cells with maslinic acid. Morphologically, maslinic acid did not induce any significant changes in apoptosis (A). These results were further confirmed at the molecular level by the lack of significant changes in the expression of the antiapoptotic molecule Bcl-2 (B), and the proapoptotic molecule Bax (C). U: untreated; T: treated with maslinic acid.

primers. No significant changes in the expression of $\mathrm{Bcl} 2$ (Figure 1B) or Bax (Figure 1C) were observed in response to maslinic acid treatment.

\section{Maslinic acid decreased the proliferation of RCC cell lines}

To further verify the mechanisms of maslinic acid-induced cytotoxicity, the antiproliferative activity of maslinic acid was studied. A significant decrease in proliferation of RCC cells was observed in response to maslinic acid (Figure 2A). A representative area from untreated cells and cells treated with maslinic acid is demonstrated (Figure 2B). To further confirm these findings at the molecular level, the expression of PCNA was studied by quantitative PCR using validated primers. A significant decrease in PCNA was observed in cells treated with maslinic acid (Figure 2C). Thus, the main mechanism of maslinic acid-induced cytotoxicity appears to be inhibition of proliferation rather than induction of apoptosis or cell death.
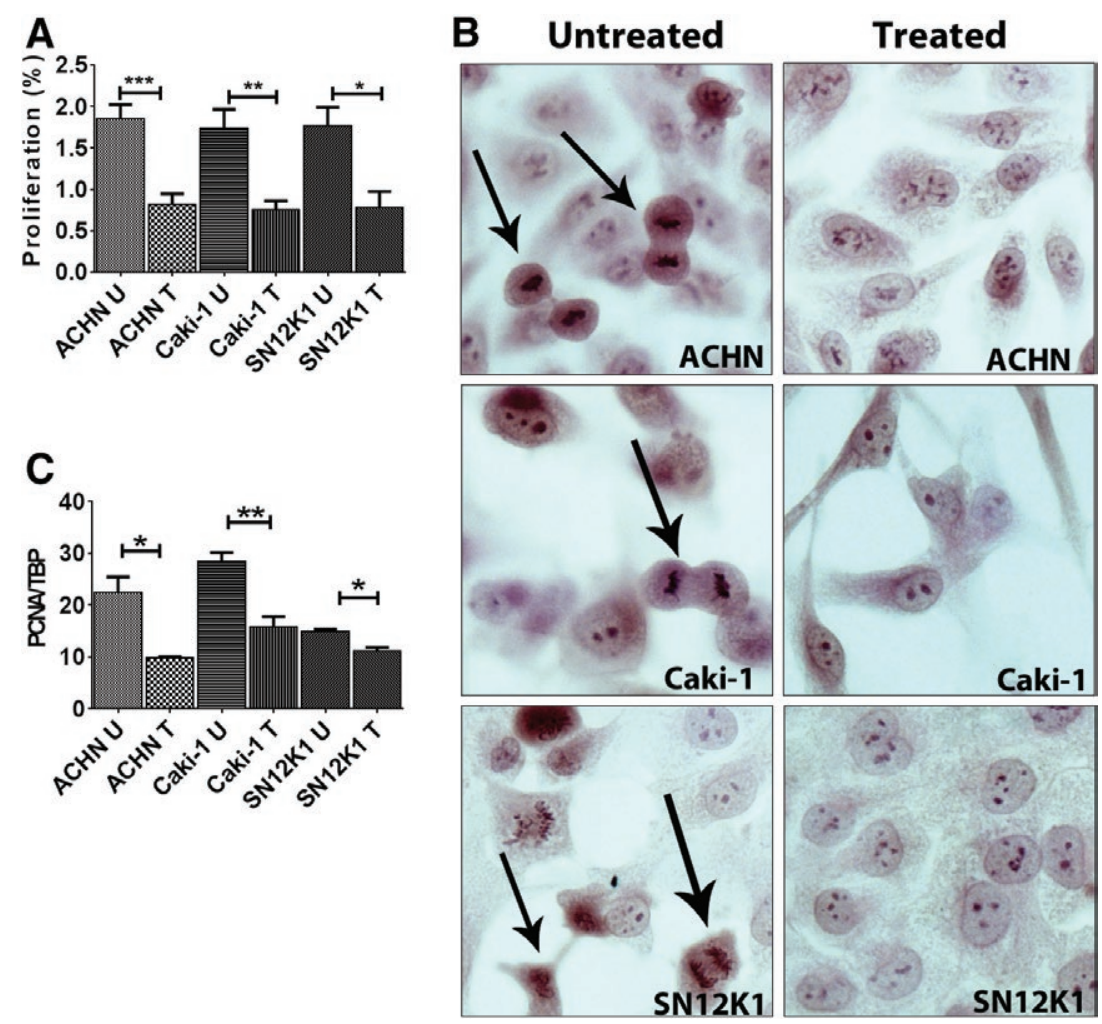

Figure 2. Maslinic acid significantly reduced the proliferation of RCC cells. Twenty-four hours after treatment, maslinic acid induced a significant reduction in proliferation of all three RCC cell lines (A). Representative images of untreated cells and cells treated with maslinic acid are demonstrated in B. Arrows highlight proliferating cells. At the molecular level, maslinic acid significantly reduced the expression of PCNA (C). ${ }^{*} P<0.05 ; * * P<0.01$, and $* * * P<0.001$. U: untreated; T: treated with maslinic acid. 


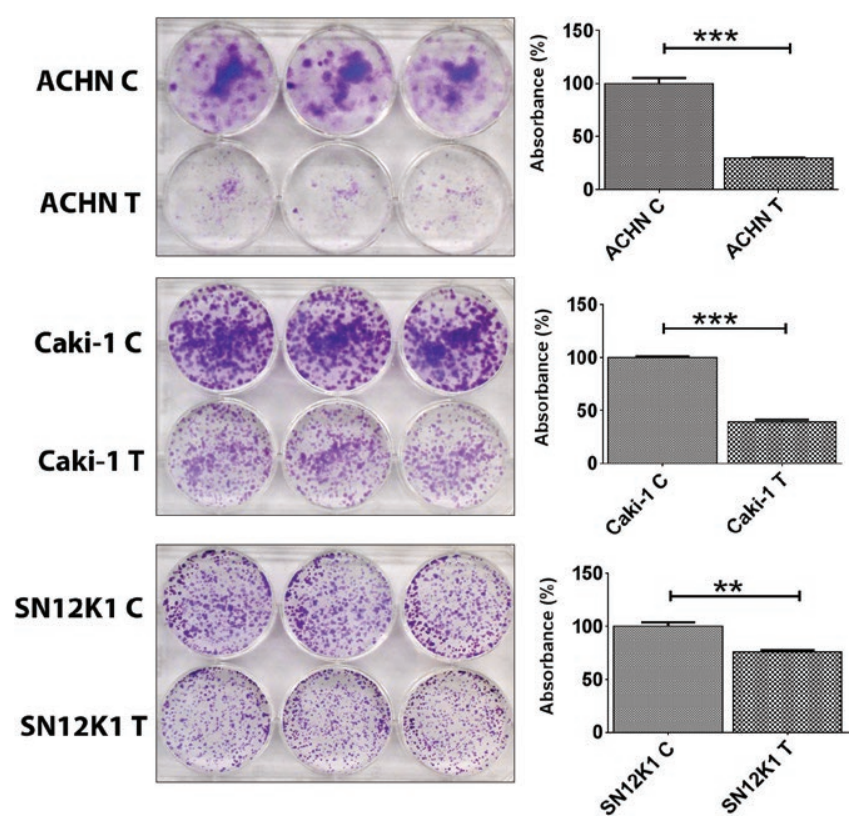

Figure 3. Maslinic acid significantly reduced colony formation. Adhesion and colony formation are essential steps in distant metastasis. Maslinic acid significantly decreased colony formation of all three cell lines. Left, representative images showing colony formation. Right, quantification of the dye. ${ }^{* *} P<0.01 ; * * * P<0.001$. C: untreated control; T: treated with maslinic acid.

\section{Maslinic acid inhibited colony formation}

Once a cell has detached from a primary tumor, it must attach to a distant part of the body to grow and metastasise. The colony formation assay is one of the measures to study adhesion. Maslinic acid induced a significant decrease in colony formation of ACHN, Caki-1, and SN12K1 cell lines (Figure 3).
The number of colonies in the treated and nontreated groups appeared similar although the size of the colonies was smaller in the treated groups, further confirming the antiproliferative effect of maslinic acid. Quantification of the dye showed a significant decrease in cells treated with maslinic acid (graphs on the right side beside each photo-
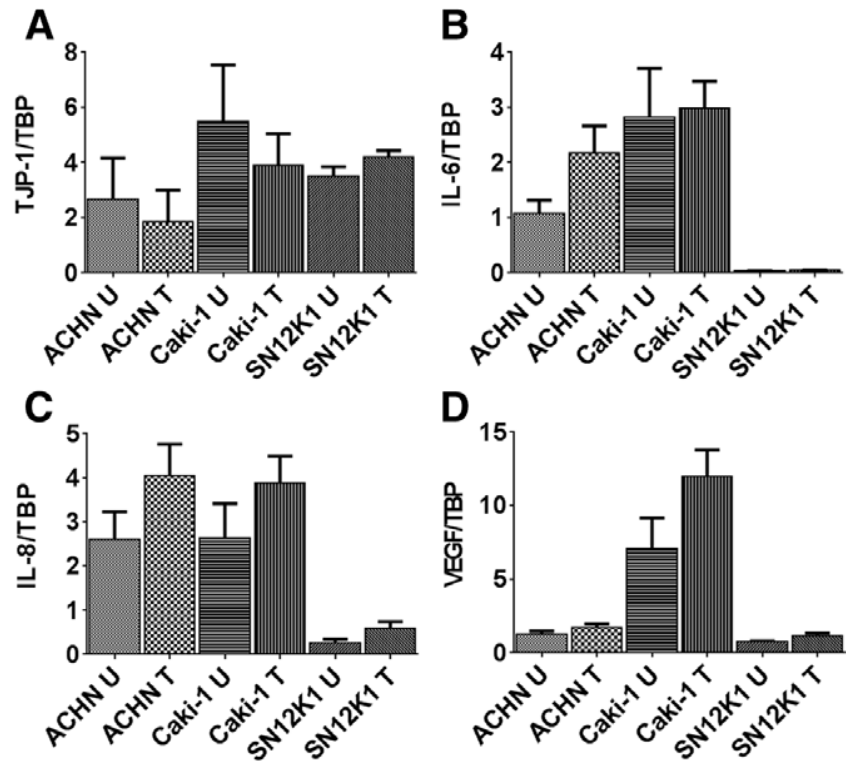

Figure 4. Lack of effect of maslinic acid on markers of RCC progression. Analysis of TJP-1 (A), the IL-6 (B), IL-8 (C), and VEGF (D) did not show any significant changes in response to maslinic acid. These results further confirm that the primary effect of maslinic acid on RCC cell lines is inhibition of proliferation. U: untreated; T: treated with maslinic acid. 
graph). Analysis of some of the molecular markers, TJP-1 (Figure 4A), IL-6 (Figure 4B), IL-8 (Figure 4C), and VEGF (Figure 4D), implicated in adhesion and metastasis, showed no significant changes between the control and treatment groups.

\section{Maslinic acid inhibited in vitro angiogenesis}

The antiangiogenic activity of maslinic acid was studied using an in vitro tube formation assay in HUVEC. Maslinic acid significantly decreased tube formation of HUVEC (Figure 5A and B). Quantification showed a significant decrease in the number (Figure 5C) and the length (Figure 5D) of tubes. To verify that the observed effect of maslinic acid was antiangiogenesis per se, not cell death, an MTT assay was performed. For this, HUVEC were dispersed in culture medium with or without maslinic acid $(24 \mu \mathrm{M})$. The cells were then seeded on 96 -well plates at a density of $\left(3 \times 10^{4}\right.$ cells $\left./ 100 \mu \mathrm{l}\right)$. After 6 hours, the MTT assay was performed as described previously. No significant death of HUVEC was observed (Figure 5E), confirming independent antiangiogenic activity. To elucidate the molecular mechanism, the expression VEGF was studied. A significant decrease in VEGF was observed in response to maslinic acid (Figure 5F).

\section{Discussion}

Despite the introduction of many targeted therapies in the past decade, metastatic RCC continues to be a treatmentresistant malignancy. A need exists for the identification of more effective novel therapeutics. Plant-based natural compounds as anticancer agents have been a subject of intense research and have produced some positive outcomes in the
A

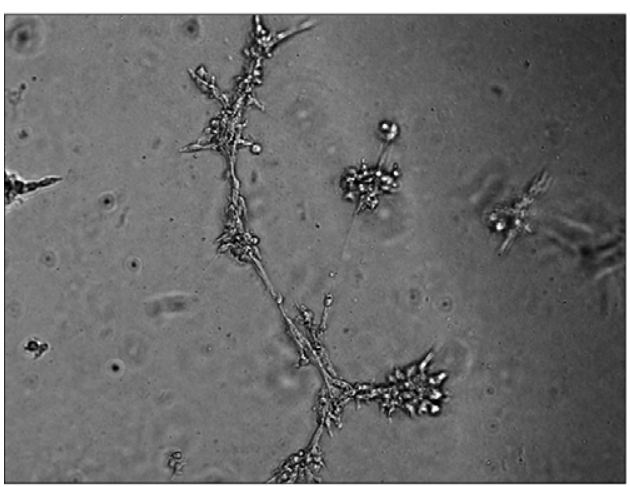

B
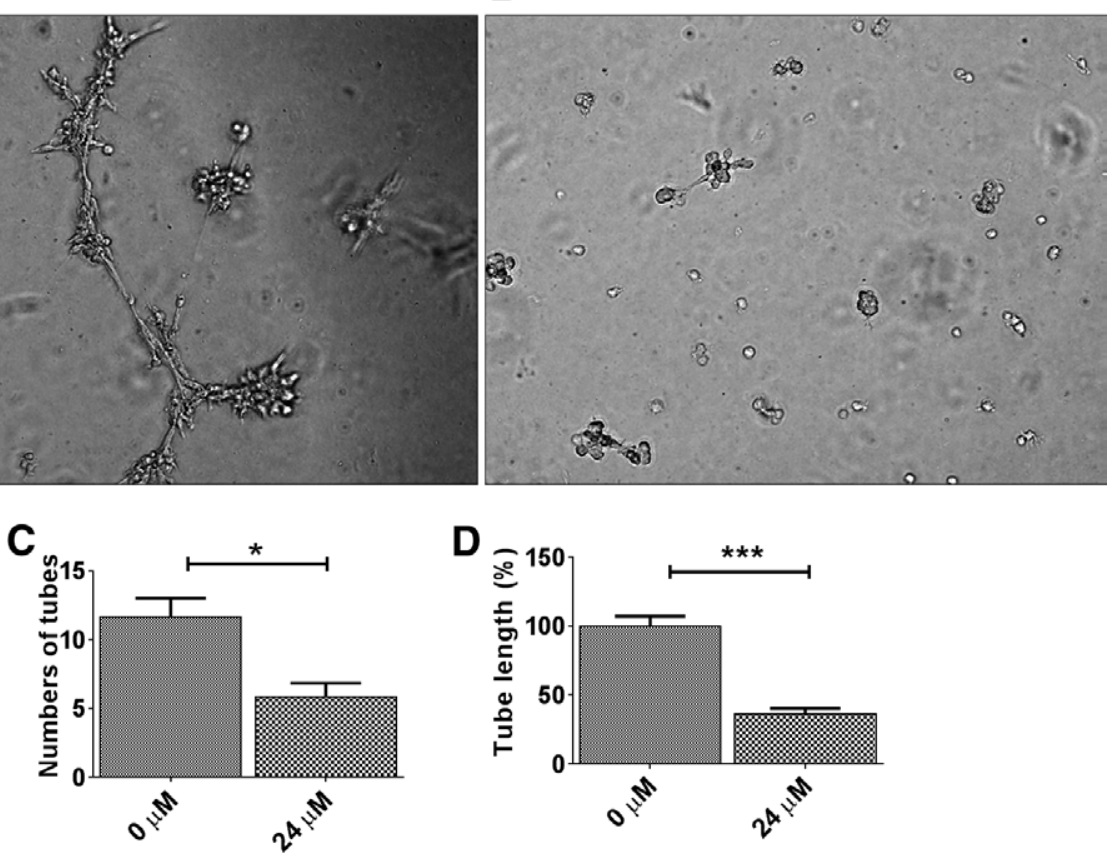

E

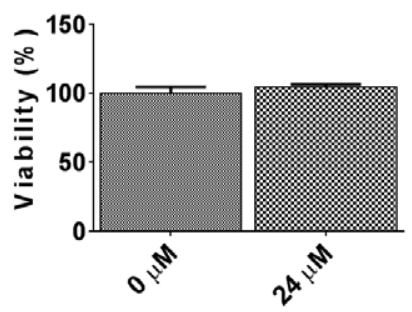

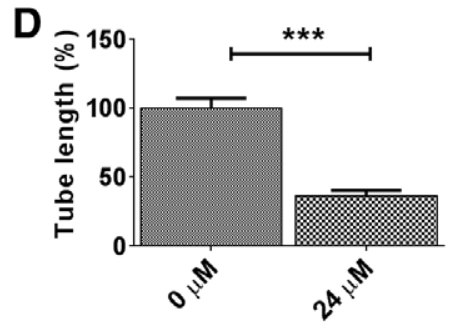

$\mathbf{F}$

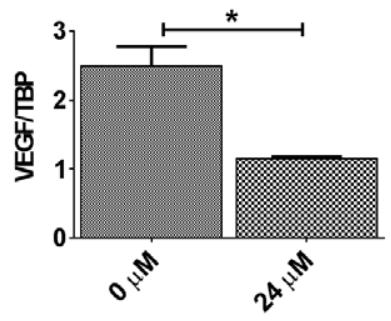

Figure 5. Maslinic acid inhibited in vitro angiogenesis. HUVEC in the untreated group formed enclosed network like structures (A), which was prevented by maslinic acid (B). Average number of tubes per field (C) and tube length (D) expressed as percentage in relation to control, are shown. Maslinic acid did not induce significant changes in viability of HUVEC (E), which confirms that the antiangiogenic activity of maslinic acid is independent of its cytotoxicity. F, Maslinic acid decreased the expression of VEGF in endothelial cells. $* P<0.05$ and $* * * P<0.001$. 


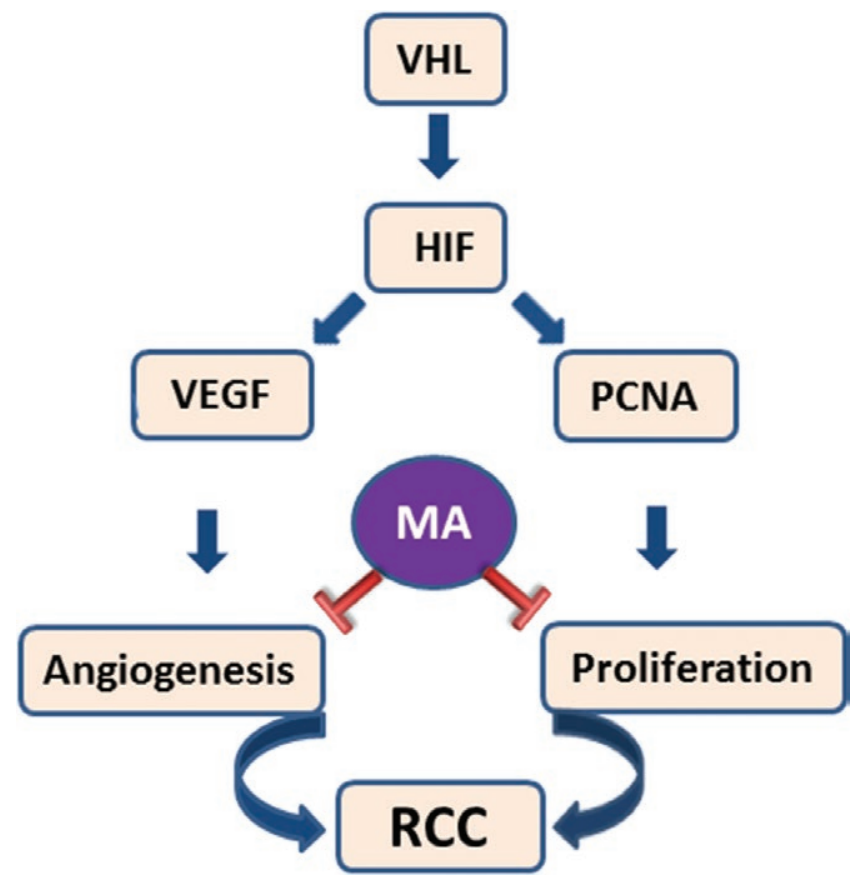

Figure 6. Putative role of maslinic acid on proliferation and angiogenesis. Aberrations of von Hippel-Lindau gene (VHL) are the major risk factors for RCC. Inactivated VHL leads to the upregulation of hypoxia-inducible factor (HIF), which in turn leads to the upregulation of many molecules that promote RCC progression through enhanced angiogenesis and proliferation. Maslinic acid inhibits angiogenesis and proliferation possibly via the downregulation of VEGF in vascular endothelial cells and PCNA in RCC. Emphasis is given to molecules of interest from this study.

past as exemplified by the taxanes (9). Herein, we studied the anticancer effect of maslinic acid, a naturally occurring pentacyclic triterpenoid found abundantly in olives and many other plants (16), with emphasis on apoptosis and proliferation of RCC cell lines and angiogenesis of endothelial cells.

A defective apoptotic pathway is one of the hallmarks of cancer (32) and is thought to regulate cancer biology by at least two mechanisms: failure to remove aberrant cells and providing resistance to chemotherapy. The two major pathways of apoptosis regulation are the extrinsic or the deathreceptor pathway, and the intrinsic or the mitochondrial pathway $(33,34)$. The extrinsic pathway induces apoptosis through cleavage of caspase, whereas the intrinsic pathway exerts apoptosis through the modulation of the Bcl2 family of apoptosis-regulatory molecules (34). The proapoptotic effect of maslinic acid has been extensively studied in many cancer cells. Some of the reported mechanisms include the downregulation of the antiapoptotic $\mathrm{Bcl} 2$ molecules and inhibitor of apoptosis proteins and the upregulation of the proapoptotic molecules such as Bax, cleaved caspase-3, caspase-8, and caspase-9 $(15,35)$. In our study, contrary to the proapoptotic effect reported for other cancer cells, maslinic acid did not demonstrate any significant proapoptotic effects, either morphologically or at molecular level. To further investigate the mechanism of action maslinic acid, we focused on the effect on proliferation.
Maslinic acid induced a significant decrease in proliferation of the RCC cells: morphologically by a lower number of mitotic cells, reduced size of colonies, and molecularly by decreased PCNA expression. PCNA plays a crucial role in cell cycle and proliferation by appearing in the nucleus during the late G1 phase, increasing during the $\mathrm{S}$ phase, and decreasing during the G2 and M phases (36). RCC is a highly metastatic disease, and a higher expression of PCNA is thought to be an indicator of unfavorable prognosis (37). Expression of PCNA is associated with the expression of epidermal growth factor receptor, which itself is a survival factor for many cancers, including RCC. PCNA is also associated with the MYC pathway and is the target molecule of pro-oncogenic $M Y C$. Knockdown of $M Y C$ has been shown to suppress the proliferation of clear cell RCC (38). Thus, maslinic acid may directly inhibit RCC progression via the reduction of PCNA and indirectly by reducing the substrate of other oncogenic molecules. The expression pattern of TJP-1, IL-6, IL-8, and VEGF, some of the most studied molecules that are well-known players in RCC progression, showed no significant changes in response to maslinic acid.

After verifying that the mechanism of action of maslinic acid is mediated via the inhibition of proliferation rather than the induction of apoptosis, we explored its antiangiogenic actions. Due to aberrations in von Hippel Lindau gene, and subsequent activation of downstream hypoxia-inducible proangiogenic factors, $\mathrm{RCC}$ is one of the most vascularized 
solid tumors (39). The majority of the targeted therapies introduced in clinical practice in the past decade are multiTKIs, targeting the angiogenesis pathway (40). In vitro capillary tube formation assay showed that maslinic acid has antiangiogenic effects independent of its cytotoxic effects. At the molecular level, it significantly inhibited VEGF, the prime mediator of angiogenesis. VEGF expression has a correlation with tumor microvascular density, disease progression, and metastasis of RCC (41-43).

In summary, maslinic acid exerts antiproliferative and antiangiogenic activities. The putative mechanisms of action of maslinic acid, based on our results, are summarized in Figure 6. Our results on antiangiogenic and antiproliferative activities are in line with previously published reports of maslinic acid $(23-26,44)$ and other pentacyclic triterpenoic acids such as ursolic acid and oleanolic acid (44-47). It is well known that tumor type is a determinant of susceptibility to apoptosis (48) and that compounds can exert cell-specific apoptosis (49). We believe that this may be a reason why maslinic acid did not induce apoptosis in RCC cells.

In conclusion, this study provides a rationale for incorporating a maslinic acid-rich diet either to reduce the risk of developing kidney cancer or as an adjunct to existing anticancer therapy, particularly antiangiogenic therapies, to improve efficacy. Considering the need for alternative and complementary therapies for RCC, further studies are warranted to explore the antiproliferative and antiangiogenic potential of maslinic acid as a therapeutic agent for RCC.

\section{Acknowledgments}

The authors are thankful to Translational Research Institute, Brisbane core microscopy facility. P. Thakor is thankful to the Department of Education, Australia, for an Endeavour Award and DST India for an Inspire Fellowship (DST INSPIRE FELLOWSHIP/2013/44).

\section{Conflicts of interest}

The authors declare no potential conflicts of interest with respect to research, authorship, and/or publication of this article.

\section{References}

1. Soerensen AV, Donskov F, Hermann GG, Jensen NV, Petersen A, Spliid $\mathrm{H}$, et al. Improved overall survival after implementation of targeted therapy for patients with metastatic renal cell carcinoma: results from the Danish Renal Cancer Group (DARENCA) study-2. Eur J Cancer. 2014 Feb;50(3):553-62. http://dx.doi.org/10.1016/j. ejca.2013.10.010

2. Koshkin VS, Rini BI. Emerging therapeutics in refractory renal cell carcinoma. Expert Opin Pharmacother. 2016 Jun;17(9):1225-32. http://dx.doi.org/10.1080/14656566.2016.1182987.

3. Jiménez-Valerio G, Martínez-Lozano M, Bassani N, Vidal A, Ochoa-de-Olza M, Suárez C, et al. Resistance to antiangiogenic therapies by metabolic symbiosis in renal cell carcinoma PDX mod- els and patients. Cell Rep. 2016 May10;15(6):1134-43. http://dx. doi.org/10.1016/j.celrep.2016.04.015.

4. Lim SH, Hwang IG, Ji JH, Oh SY, Yi JH, Lim DH, et al. Intrinsic resistance to sunitinib in patients with metastatic renal cell carcinoma. Asia Pac J Clin Oncol. 2017 Feb;13(1):61-67. http://dx.doi. org/10.1111/ajco.12465.

5. Rini BI, Atkins MB. Resistance to targeted therapy in renal-cell carcinoma. Lancet Oncol. 2009 Oct;10(10):992-1000. http://dx.doi. org/10.1016/S1470-2045(09)70240-2.

6. Porta C, Sabbatini R, Procopio G, Paglino C, Galligioni E, Ortega C. Primary resistance to tyrosine kinase inhibitors in patients with advanced renal cell carcinoma: state-of-the-science. Expert Rev Anticancer Ther. 2012 Dec;12(12):1571-7. http://dx.doi. org/10.1586/era.12.81.

7. Busch J, Seidel C, Weikert S, Wolff I, Kempkensteffen C, Weinkauf $\mathrm{L}$, et al. Intrinsic resistance to tyrosine kinase inhibitors is associated with poor clinical outcome in metastatic renal cell carcinoma. BMC Cancer. 2011 Jul14;11:295. http://dx.doi.org/10.1186/1471-240711-295.

8. Amin A, Gali-Muhtasib H, Ocker M, Schneider-Stock R. Overview of major classes of plant-derived anticancer drugs. Int J Biomed Sci. 2009 Mar;5(1):1-11.

9. Joshi M, Liu X, Belani CP. Taxanes, past, present, and future impact on non-small cell lung cancer. Anticancer Drugs. 2014 May;25(5):57183. http://dx.doi.org/10.1097/CAD.0000000000000080.

10. Rohrmann S, Linseisen J, Overvad K, Lund Würtz AM, Roswall N, Tjonneland $\mathrm{A}$, et al. Meat and fish consumption and the risk of renal cell carcinoma in the European prospective investigation into cancer and nutrition. Int J Cancer. 2015 Mar1;136(5):E423-31. http://dx. doi.org/10.1002/ijc.29236.

11. Daniel CR, Schwartz KL, Colt JS, Dong LM. Meat-cooking mutagens and risk of renal cell carcinoma. Br J Cancer. 2011 Sep27;105(7):1096-104. http://dx.doi.org/10.1038/bjc.2011.343.

12. Hsu CC, Chow WH, Boffetta P, Moore L, Zaridze D, Moukeria A, et al. Dietary risk factors for kidney cancer in Eastern and Central Europe. Am J Epidemiol. 2007 Jul1;166(1):62-70. http://dx.doi. org/10.1093/aje/kwm043.

13. Grieb SM, Theis RP, Burr D, Benardot D, Siddiqui T, Asal NR Food groups and renal cell carcinoma: results from a case-control study. J Am Diet Assoc. 2009 Apr;109(4):656-67. http://dx.doi. org/10.1016/j.jada.2008.12.020.

14. Rashidkhani B, Lindblad P, Wolk A. Fruits, vegetables and risk of renal cell carcinoma: a prospective study of Swedish women. Int J Cancer. 2005 Jan20;113(3):451-5. http://dx.doi.org/10.1002/ ijc. 20577 .

15. Reyes-Zurita FJ, Rufino-Palomares EE, Lupianez JA, Cascante M. Maslinic acid, a natural triterpene from Olea europaea L., induces apoptosis in HT29 human colon-cancer cells via the mitochondrial apoptotic pathway. Cancer Lett. 2009 Jan8;273(1):44-54. http://dx. doi.org/10.1016/j.canlet.2008.07.033.

16. Lozano-Mena G, Sanchez-Gonzalez M, Juan ME, Planas JM. Maslinic acid, a natural phytoalexin-type triterpene from olives-a promising nutraceutical? Molecules. 2014 Aug4;19(8):11538-59. http://dx.doi.org/10.3390/molecules190811538.

17. Montilla MP, Agil A, Navarro MC, Jiménez MI, García-Granados A, Parra A, et al. Antioxidant activity of maslinic acid, a triterpene derivative obtained from Olea europaea. Planta Med. 2003 May;69(5):472-4. http://dx.doi.org/10.1055/s-2003-39698.

18. Huang L, Guan T, Qian Y, Huang M, Tang X, Li Y, et al. Antiinflammatory effects of maslinic acid, a natural triterpene, in cultured cortical astrocytes via suppression of nuclear factor-kappa B. Eur J Pharmacol. 2011 Dec15;672(1-3):169-74. http://dx.doi. org/10.1016/j.ejphar.2011.09.175. 
19. Moneriz C, Mestres J, Bautista JM, Diez A, Puyet A. Multi-targeted activity of maslinic acid as an antimalarial natural compound. FEBS J. 2011 Aug;278(16):2951-61. http://dx.doi.org/10.1111/j.17424658.2011.08220.x.

20. De Pablos LM, González G, Rodrigues R, García Granados A, Parra A, Osuna A. Action of a pentacyclic triterpenoid, maslinic acid, against Toxoplasma gondii. J Nat Prod. 2010 May28;73(5):831-4. http://dx.doi.org/10.1021/np900749b.

21. Liu J, Sun H, Duan W, Mu D, Zhang L. Maslinic acid reduces blood glucose in KK-Ay mice. Biol Pharm Bull. 2007 Nov;30(11):2075-8. http://dx.doi.org/10.1248/bpb.30.2075.

22. Parra A, Rivas F, Lopez PE, Garcia-Granados A, Martinez A, Albericio F, et al. Solution- and solid-phase synthesis and anti-HIV activity of maslinic acid derivatives containing amino acids and peptides. Bioorg Med Chem. 2009 Feb1;17(3):1139-45. http://dx.doi. org/10.1016/j.bmc.2008.12.041.

23. Park SY, Nho CW, Kwon DY, Kang YH, Lee KW, Park JH. Maslinic acid inhibits the metastatic capacity of DU145 human prostate cancer cells: possible mediation via hypoxia-inducible factor-1alpha signalling. Br J Nutr. 2013 Jan28;109(2):210-22. http://dx.doi. org/10.1017/S0007114512000967.

24. Zhang S, Ding D, Zhang X, Shan L, Liu Z. Maslinic acid induced apoptosis in bladder cancer cells through activating p38 MAPK signaling pathway. Mol Cell Biochem. 2014 Jul;392(1-2):281-7. http://dx.doi.org/10.1007/s11010-014-2038-y.

25. Hsia TC, Liu WH, Qiu WW, Luo J, Yin MC. Maslinic acid induces mitochondrial apoptosis and suppresses HIF-1alpha expression in A549 lung cancer cells under normoxic and hypoxic conditions. Molecules. 2014 Nov28;19(12):19892-906. http://dx.doi. org/10.3390/molecules191219892.

26. Li C, Yang Z, Zhai C, Qiu W, Li D, Yi Z, Wang L, et al. Maslinic acid potentiates the anti-tumor activity of tumor necrosis factor alpha by inhibiting NF-kappaB signaling pathway. Mol Cancer. 2010 Apr6;9:73. http://dx.doi.org/10.1186/1476-4598-9-73.

27. Morais C, Westhuyzen J, Pat B, Gobe G, Healy H. High ambient glucose is effect neutral on cell death and proliferation in human proximal tubular epithelial cells. Am J Physiol Renal Physiol. 2005 Aug;289(2):F401-9. http://dx.doi.org/10.1152/ajprenal.00408.2004.

28. Morais C, Pat B, Gobe G, Johnson DW, Healy H. Pyrrolidine dithiocarbamate exerts anti-proliferative and pro-apoptotic effects in renal cell carcinoma cell lines. Nephrol Dial Transplant. 2006 Dec;21(12):3377-88. http://dx.doi.org/10.1093/ndt/gfl543.

29. Kerr JF, Wyllie AH, Currie AR. Apoptosis: a basic biological phenomenon with wide-ranging implications in tissue kinetics. Br J Cancer. 1972 Aug;26(4):239-57. http://dx.doi.org/10.1038/bjc.1972.33.

30. Morais C, Gobe G, Johnson DW, Healy H. Anti-angiogenic actions of pyrrolidine dithiocarbamate, a nuclear factor kappa B inhibitor. Angiogenesis. 2009;12(4):365-79. http://dx.doi.org/10.1007/ s10456-009-9158-0.

31. Morais C,Ebrahem Q,Anand-Apte B, ParatMO.Altered angiogenesis in caveolin-1 gene-deficient mice is restored by ablation of endothelial nitric oxide synthase. Am J Pathol. 2012 Apr;180(4):1702-14. http://dx.doi.org/10.1016/j.ajpath.2011.12.018.

32. Hanahan D, Weinberg RA. Hallmarks of cancer: the next generation. Cell. 2011 Mar4;144(5):646-74. http://dx.doi.org/10.1016/j. cell.2011.02.013.

33. Nam YJ, Mani K, Ashton AW, Peng CF, Krishnamurthy B, Hayakawa $\mathrm{Y}$, et al. Inhibition of both the extrinsic and intrinsic death pathways through nonhomotypic death-fold interactions. Mol Cell. 2004 Sep24;15(6):901-12. http://dx.doi.org/10.1016/j.molcel.2004. 08.020 .

34. Ola MS, Nawaz M, Ahsan H. Role of Bcl-2 family proteins and caspases in the regulation of apoptosis. Mol Cell Biochem.
2011 May;351(1-2):41-58. http://dx.doi.org/10.1007/s11010-0100709-x.

35. Bai X, Zhang Y, Jiang H, Yang P, Li H, Zhang Y, et al. Effects of maslinic acid on the proliferation and apoptosis of A549 lung cancer cells. Mol Med Rep. 2016 Jan;13(1):117-22.

36. Dirim A1, Haberal AN, Goren MR, Tekin MI, Peskircioglu L, Demirhan B, et al. VEGF, COX-2, and PCNA expression in renal cell carcinoma subtypes and their prognostic value. Int Urol Nephrol. 2008;40(4):861-8. http://dx.doi.org/10.1007/s11255-008-9362-7.

37. Amare Kadam PS, Varghese C, Bharde SH, Narasimhamoorthy NK, Desai S, Advani SH, et al. Proliferating cell nuclear antigen and epidermal growth factor receptor (EGFr) status in renal cell carcinoma patients with polysomy of chromosome 7. Cancer Genet Cytogenet. 2001 Mar;125(2):139-46. http://dx.doi.org/10.1016/ S0165-4608(00)00375-7.

38. Tang SW, Chang WH, Su YC, Chen YC, Lai YH, Wu PT, et al. MYC pathway is activated in clear cell renal cell carcinoma and essential for proliferation of clear cell renal cell carcinoma cells. Cancer Lett. 2009 Jan8;273(1):35-43. http://dx.doi.org/10.1016/j. canlet.2008.07.038.

39. Rini BI, Small EJ. Biology and clinical development of vascular endothelial growth factor-targeted therapy in renal cell carcinoma. J Clin Oncol. 2005 Feb10;23(5):1028-43. http://dx.doi.org/10.1200/ JCO.2005.01.186.

40. Posadas EM, Limvorasak S, Sharma S, Figlin RA. Targeting angiogenesis in renal cell carcinoma. Expert Opin Pharmacother. 2013 Nov;14(16):2221-36. http://dx.doi.org/10.1517/14656566.2013.832202.

41. Takahashi A, Sasaki H, Kim SJ, Tobisu K, Kakizoe T, Tsukamoto $\mathrm{T}$, et al. Markedly increased amounts of messenger RNAs for vascular endothelial growth factor and placenta growth factor in renal cell carcinoma associated with angiogenesis. Cancer Res. 1994 Aug1;54(15):4233-7.

42. Zhang X, Yamashita M, Uetsuki H, Kakehi Y. Angiogenesis in renal cell carcinoma: Evaluation of microvessel density, vascular endothelial growth factor and matrix metalloproteinases. Int $\mathrm{J}$ Urol. 2002 Sep;9(9):509-14. http://dx.doi.org/10.1046/j.14422042.2002.00511.x.

43. Rioux-Leclercq N, Fergelot P, Zerrouki S, Leray E, Jouan F, Bellaud $\mathrm{P}$, et al. Plasma level and tissue expression of vascular endothelial growth factor in renal cell carcinoma: a prospective study of 50 cases. Hum Pathol. 2007 Oct;38(10):1489-95. http://dx.doi. org/10.1016/j.humpath.2007.02.014.

44. Lin CC, Huang CY, Mong MC, Chan CY, Yin MC. Antiangiogenic Potential of Three Triterpenic Acids in Human Liver Cancer Cells. J Agric Food Chem. 2011 Jan26;59(2):755-62. http://dx.doi. org/10.1021/jf103904b.

45. Ovesná Z, Vachálková A, Horváthová K, Tóthová D. Pentacyclic triterpenoic acids: new chemoprotective compounds. Minireview. Neoplasma. 2004;51(5):327-33.

46. Sohn KH, Lee HY, Chung HY, Young HS, Yi SY, Kim KW. Anti-angiogenic activity of triterpene acids. Cancer Lett. 1995 Aug1;94(2):2138. http://dx.doi.org/10.1016/0304-3835(95)03856-R

47. Sogno I, Vannini N, Lorusso G, Cammarota R, Noonan DM, Generoso L, et al. Anti-angiogenic activity of a novel class of chemopreventive compounds: oleanic acid terpenoids. Recent Results Cancer Res. 2009;181:209-12.

48. Staunton MJ, Gaffney EF. Tumor type is a determinant of susceptibility to apoptosis. Am J Clin Pathol. 1995 Mar;103(3):300-7. http://dx.doi.org/10.1093/ajcp/103.3.300.

49. Qazi AK, Hussain A, Aga MA, Ali S, Taneja SC, Sharma PR, et al. Cell specific apoptosis by RLX is mediated by NFאB in human colon carcinoma HCT-116 cells. BMC Cell Biol. 2014 Oct10;15:36. http://dx.doi.org/10.1186/1471-2121-15-36. 